ENTREPRENEURSHIP AND SUSTAINABILITY ISSUES

ISSN 2345-0282 (online) http://jssidoi.org/jesi/

2021 Volume 8 Number 3 (March)

http://doi.org/10.9770/jesi.2021.8.3(24)

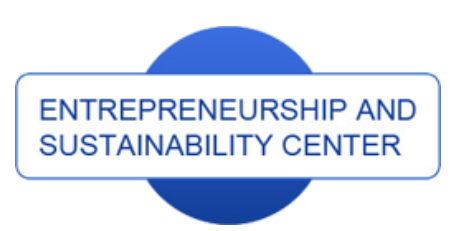

Publisher

$\underline{\text { http://jssidoi.org/esc/home }}$
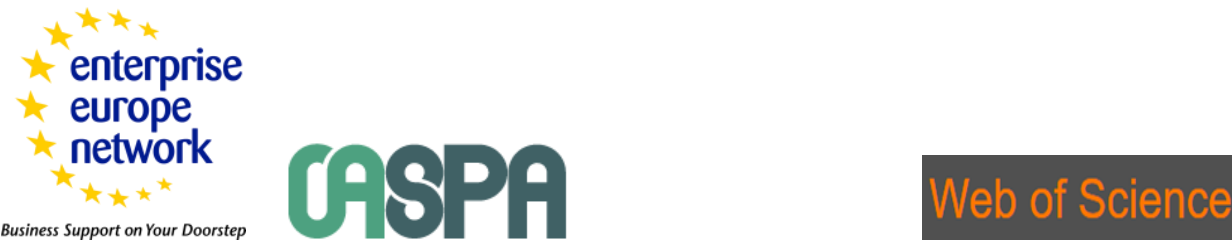

1 Clarivate

Analytics

\title{
LAYER AND STRUCTURAL COMPONENTS OF MODERN INVESTMENT SECURITY OF THE COUNTRY
}

\section{Lidiia Karpenko ${ }^{1}$ Oleksandr Ignatenko ${ }^{2}$, Olena Taranenko ${ }^{3}$, Iryna Oliinyk ${ }^{4}$, Ripsime Khrenova-Shymkina ${ }^{5}$}

\author{
${ }^{1 *}$ Odessa Regional Institute for Public Administration of the National Academy for Public Administration under the President of Ukraine, \\ Genuezka, 22, 65009, Odessa, Ukraine \\ 2,3,4,5 National Academy for Public Administration under the President of Ukraine, 20, Ezhena Pottier st., 03057 Kyiv, Ukraine
}

E-mail: ${ }^{*}$ karpenko_l@i.ua

Received 15 May 2020; accepted 10 January 2021; published 30 March 2021

\begin{abstract}
The article considers the structure of components of the country's investment security as part of ensuring general national economic safety. It was determined that the Investment component of economic security takes a determining place in the country's economic security, while the provision of the economic security and implementation of the national interests should form the investment policy of the country. The authors identified styles and models of the Investment behavior under the condition of achievement or ignoring of the proper level of investment security, they formed the directions for adherence and monitoring of the country's investment security. They supplemented the classification parameters of types of the country's investment security. They also built a model of the integrated investment security provision at different managerial levels of the national economy; they proved the availability of a stable interrelation and interdependence between the components of the country's investment security. The country's investment security was proved to be considered as the achievement of the investment level, which makes it possible to please current investment needs of the national economy in terms of volume and structure of investments, with the consideration of efficient use and repayment, the optimal correlation between volumes of domestic and external investments, foreign investments in the country and domestic ones abroad, the formation of the favorable national balance of payments.
\end{abstract}

Keywords: country's investment security; economic security; direct and portfolio investments; Investment behavior; accumulation of gross investments

Reference to this paper should be made as follows: Karpenko, L., Ignatenko, O., Taranenko, O., Oliinyk, I., Khrenova-Shymkina, R. 2021. Layer and structural components of modern investment security of the country. Entrepreneurship and Sustainability Issues, 8(3), 367-383. http://doi.org/10.9770/jesi.2021.8.3(24)

JEL Classifications: F35, F42 


\section{ENTREPRENEURSHIP AND SUSTAINABILITY ISSUES}

ISSN 2345-0282 (online) http://jssidoi.org/jesi/

2021 Volume 8 Number 3 (March)

http://doi.org/10.9770/jesi.2021.8.3(24)

Make your research more visible, join the Twitter account of ENTREPRENEURSHIP AND SUSTAINABILITY ISSUES: @Entrepr69728810

\section{Introduction}

The development of the globalization processes, the domination of international investment relationships between the world countries, improvement of competition for direct foreign investments, increase in the domestic investment of the foreground industries of the economic complexes increasingly affect the growth of the national economies. Nonetheless, as of today, those countries, which are currently developing due to political transformations, crises occurrence in the sectors of the national economy and the financial system, in particular, the absence of substantiated economic and financial policies, practical self-removal of state authorities from regulation and implementation of investment processes, a huge level of public relations corruption, and, hence the absence of a proper investment climate are not able to increase their domestic investment and lose the competitive struggle for foreign investments and corporate interests. Moreover, in the developing countries, there is still a flight of capital abroad, it is possible to observe the irrational sectoral and regional distribution of available investment resources, which preserves an imperfect structure of the national economy of raw materials type and significantly reduces its competitiveness by fixing the technological gap, it increases the dependence of the domestic producers on the world markets conjuncture, and increases the volumes of financing of foreign economies. Herewith, a considerable share of savings does not transform into investments, leaving the channels of inter-industry and inter-regional capital overflow underdeveloped. This all, undoubtedly, requires the fastest and quality development of the investment processes with the consideration of the proper investment security.

\section{Literature Survey}

Numerous writings on the problems of the country's economic security reveal the notion and content of the investment security category in theoretical and practical aspects. At the same time, there are a lack of publications on the key components of economic security, namely, the ones dedicated to investment security problems. Moreover, the content of the notion of investment security requires clarification as well as the mechanisms of the investment security provision. As of today, the investment and economic security of any country are affected by internal and external threats. Thus, the main task any country faces is the creation of an effective reactive mechanism. As noted by (Aitken \& Harrison 1999; De Gregorio 2003; Chehabeddine \& Tvaronavičienè, 2020), the threats to economic security are the factors, which complicate self-regulation of the economy and implementation of the economic interests, lead to the movement of the economic indicator beyond the normative or border values.

The country's investment security can be provided under the condition if one provides all conditions, required for satisfaction of interest and needs in the long term run; generation of innovative shifts in the economy; standing up to external threats, and use of the national competitive advantages (Xiao \& Dickie 2000).

The research papers of (Barro \& Sala-I-Marting 2003; Eden 2012) state that the organization of investments should be the basis for the provision of economic security as the growth of investments should stimulate economic activity, and growth in demand, which, in its turn, will lead to an increase in employment and national income, i.e. to the realization of national interests. The researchers (Callanan 2000; Lall 2000) mention that capital accumulation should be considered as the most important condition for economic growth and surmounting the crisis. Both the degree of investment activity and tempos of the stock capital recovery will depend on the dynamics and investment volumes.

In particular, Azam et. al. (2016); Vasconcelos (2021) determine the investment component of economic security as the totality of legal and regulatory, social, and ecological conditions, which determine the type and dynamics of 


\section{ENTREPRENEURSHIP AND SUSTAINABILITY ISSUES}

ISSN 2345-0282 (online) http://jssidoi.org/jesi/

2021 Volume 8 Number 3 (March)

http://doi.org/10.9770/jesi.2021.8.3(24)

Make your research more visible, join the Twitter account of ENTREPRENEURSHIP AND SUSTAINABILITY ISSUES: @Entrepr69728810

the reproduction process, provide the reliability of refund, and efficiency of the invested capital. The author considers investment security as a capability to maintain production accumulations and capital investing at the level, providing the required tempos of extended reproduction, restructuration, and technological retooling of the national economy.

As noted by (Gestrin \& Novik 2015; Xu 2000), investment security calls for the provision of such investment quotes, which (in terms of volume and structure) meet the relevant requirements of the economy. Such authors as (Borensztein et. al. 1998) identify investment security as the one, "providing economically sound reproduction of the stock capital and intellectual human capital with a focus on the growth of the economic results, the improvement of production efficiency, quality of produced goods and services, and social standards of living."

The aim of the study is to determine the principal components of the formation of investment security of the country in the context of transformations and modern challenges and to develop methodological recommendations for the development of investment security at various management levels of the national economy. The main objectives of the study are: a) to investigate the investor's behavior models in the conditions of achieving investment security; b) to determine the relationship between the investment component of economic security and investment policy within the national economy; c) identify and methodically justify the leading components of the country's investment security.

The country's investment activity is achieved under the condition of adherence to the border norm of investment, which makes it possible to reproduce the scientific-and-technical and intellectual potential of the nation; carry out extended reproduction of the stock capital; maintain the competitiveness of the economy; guarantee the GDP growth at the level of the social-economic growth tasks, and international cooperation; create strategic reserves; overcome depressive phenomena in the country's regions; preserve and reproduce natural resources; keep the ecological parameters at a safe level.

\section{Methods}

Considering that economy is one of the vital spheres of activity of the society, the country, and personality, the problem of determining a place of investment security in the system of economic security of the country is primarily related to the assessment of the economy's viability, its strength under possible internal and external threats. From the methodological point of view, we will ground on the following methods and approaches: 1) a criterion approach. Let us consider the indicators, characterizing the limit value of investment activity, as the criteria of the country's investment security, under the excess of which it is impossible to provide stability of the economy's development following the objectives of social development and tasks of the country's national security provision. Thus, the investment component of economic security is a peculiar subsystem of economic security, which creates prerequisites for better use of social and economic relationships in the development and scientific and technical restoration of productive forces of society through active investment activity. 2) The investment process method. Investments are one of the most moving elements of total expenditure. In view of this, the investment component is the most mobile system, characterizing investment activity conditions, and should cover a range of interrelated indicators. The assessment of the investment component of economic security is of crucial importance; its indicators are the growth of gross investments and the efficiency of their use. The question of assessing investment security of the real sector of both the country and the region belongs to the least studied ones. Modern scientific researches refer, primarily, the general economic aspects, leaving the peculiarities of the investment process without proper attention. Under such conditions, one faces a need for special research of the questions of guaranteeing investment security of the national economy as well as the development of a system 


\section{ENTREPRENEURSHIP AND SUSTAINABILITY ISSUES}

ISSN 2345-0282 (online) http://jssidoi.org/jesi/

2021 Volume 8 Number 3 (March)

http://doi.org/10.9770/jesi.2021.8.3(24)

Make your research more visible, join the Twitter account of ENTREPRENEURSHIP AND SUSTAINABILITY ISSUES: @Entrepr69728810

of the corresponding indicators. 3) An indicative method. The most difficult moment in solving these tasks is the formation of a system of indicators, characterizing investment security. The indicators should reflect the level of the remoteness of the real sector's current state of the economy from the border of security. It is worth mentioning that there is a direct and reverse system of relationship between investments and economic dynamics: the development of investments into a real economic activity promotes economic growth, and vice versa, the decrease in investments may lead to the economic slowdown. We can use the notion of a multiplier (K) by determining the dependence between the growth of economic results, which are assessed by GDP, and the growth of the investment volume (I), i.e. GDP=KI. Although this dependence in the real economy is affected by many other macroeconomic factors (labor, financial, etc.), it can be considered as the theoretical and methodological foundation for determining investment macroeconomic security.

\section{Results}

The depth and comprehensiveness of studying investment behavior and safety are largely determined by the selected cognition methodology. Investment behavior is always associated with limiting. If there were no limitations, there would not be the need for investment designing, decision making, development of variants for the objectives achieving within the national economy. The limitations can be of financial, monetary, and credit, legal, institutional, and informational nature. Thus, the material restrictions may appear due to a lack of production space, raw materials, energy, etc. The material restrictions also cover the lack of employees of the required qualification, specialists in certain fields of activity. The financial restraints are expressed by the lack of monetary capital (sources of financing and crediting). The legal restrictions are reflected in the peculiarities of performance of specific powers (for example, an investor does not possess all the necessary powers in his sphere of competence), the existence of state legal conditions of business, the need for legal registration of specific operations. The institutional limitations occur, on one hand, due to the absence of the organizations of a specific type, which will be able to speed up and cheapen decision making, lower the risk of investing, on the other hand due to the existence of those state system links, which slowdown the investment flow. Apart from those cases, the institutional restrictions may also appear due to the existence of specific moral conditions of the investor's activity in a particular socio-economic system (William 2016). The informational limitations are most important are of great importance for understanding the nature of investment behavior and investment security. For an investor, a vital atmosphere is the availability of information about a wide range of phenomena and events, surrounding him. Depending on the nature of the restrictions, investment behavior can take various forms. Thus, if the existing restrictions are determined by objective regularities of productive forces functioning, the nature of the established economic system, the legal order, and the subject cannot overcome them, this weakens the independence of his actions in the decision-making situations, concerning the objectives and means of investment, simplifies the function of the choice of the spheres and instruments of the capital formation. Such behavior can be regarded as the normative-limited as the investor acts within strictly set technical, economical, and legal norms, where the obedience to norms - fixing the preliminarily permissible target actions and ways or their achievement - takes an important place. Such investment behavior may be based on a continuing habit or custom. Thus, so many investors prefer working with the investment instruments, that they have already given a good account of themselves, and are reluctant to work with the new ones. Of particular importance for this behavioral pattern are various effects, bearing the name of the behavioral phenomena. Thus, the behavior of the entity may be conditioned by the behavior of people (the imitation effect), surrounding it. "In his everyday life, a person makes investment decisions, based on the behavior of other people, which seems to be well-grounded and rational to him." (Benmamoun and Lehnert 2013). Phenomena play an important role in such behavior. They see the world thanks to mass-media information and communication, individual stereotypes, the opinion about friends and acquaintances. The majority of the financial pyramids and trust societies are built on such behavioral effects. 
ENTREPRENEURSHIP AND SUSTAINABILITY ISSUES

ISSN 2345-0282 (online) http://jssidoi.org/jesi/

2021 Volume 8 Number 3 (March)

http://doi.org/10.9770/jesi.2021.8.3(24)

Make your research more visible, join the Twitter account of ENTREPRENEURSHIP AND SUSTAINABILITY ISSUES: @Entrepr69728810

The second type of investment behavior and investment security provision, which can be defined as unlimited, grounds on the assumption that there is complete accessibility of required resources, and, above all - there are no transactional costs for data collection and processing, which makes it possible for the investor to consider all available opportunities. "The expenses, related to decision-making, the possibility of an error, and, often, the expenses for the acquisition of the information belong in the theories, based on full rationality, to a category of the homogeneous ones" (Moran 1998). Under such a type of behavior, the optimality and uniqueness of the result assume the process of decision-making to be made through a simple algorithm of action (the expenses for decision-making should be minimal). Such a condition is realized if the investor's capabilities in the area of data obtaining and processing are compared with the volume of coming information and complexity of the set task. This type of behavior is rather a theoretical assumption than a practical reality, nevertheless, its existence is quite acceptable and theoretically justified, as it makes it possible to understand the nature of the investment behavior. To some extent, the unlimited investment behavior is typical for a monopolist, as its marginal costs on the data search and collection for him are always lower than the marginal utility of its use.

The limited investment behavior is the main type of investment behavior, under which the investor's activity is carried out under various types of restrictions. Such behavior results from the existence of the market uncertainty, asymmetric distribution of information, and its asynchronous nature. Under such circumstances, the investor cannot predict all possible situations and calculate the optimal line of behavior and provide the proper level of investment security. Under the limited type of behavior, the choice procedure is carried out with the consideration of transactional expenses, playing the role of the selection criteria, while the selection process itself covers the number of alternatives; the nature of the set tasks (clear and one-dimensional or uncertain and multidimensional); the degree of their reproduction or repeatability; the availability and accessibility of information; corresponding motivations and stimuli (Hermes \& Lensik 2003).

Thus, investment entities differ upon the possibilities of obtaining and ways of the information use for making investment decisions and expectations, corresponding to them. Assuming that an investor can get and process all the necessary information for decision making, then his behavior can be regarded as purposeful rational. Under such a model, we understand the behavior, based on a thoughtful, cautious, and rational attitude to objective achievement. Such behavior grounds on the investor's ability to use calculations, knowledge, and assessment under the condition of uncertainty, based not only on his personal experience but also on the generalized experience, bearing the name of the investment security. Otherwise, behavior can be of purposeful rational nature, under which the objective achievement is carried out under the excessive use of the institutional instruments. There are peculiar styles and scenarios per each model. The correlation of styles, instruments, and their primary features upon the selected model is given in Table 1. 
ENTREPRENEURSHIP AND SUSTAINABILITY ISSUES

ISSN 2345-0282 (online) http://jssidoi.org/jesi/

2021 Volume 8 Number 3 (March)

http://doi.org/10.9770/jesi.2021.8.3(24)

Make your research more visible, join the Twitter account of ENTREPRENEURSHIP AND SUSTAINABILITY ISSUES: @Entrepr69728810

Table 1. Styles and models of investor behavior under the condition of achievement or ignoring of the proper level of investment security

\begin{tabular}{|c|c|c|c|c|}
\hline Investment style & $\begin{array}{c}\text { Investment } \\
\text { objective }\end{array}$ & Type of tool & Main features & Behavior models \\
\hline Conservative & $\begin{array}{c}\text { Hedge against } \\
\text { inflation }\end{array}$ & $\begin{array}{c}\text { Estate property, collectibles, state } \\
\text { valuable securities, capital stocks, } \\
\text { and loan stocks of developed stable } \\
\text { components }\end{array}$ & $\begin{array}{c}\text { A low-risk level, high } \\
\text { reliable, but low- } \\
\text { profit }\end{array}$ & $\begin{array}{c}\text { Mainly single- } \\
\text { dimensional, passive, } \\
\text { ordinary }\end{array}$ \\
\hline $\begin{array}{c}\text { Moderately- } \\
\text { aggressive }\end{array}$ & $\begin{array}{c}\text { Long-term } \\
\text { capital } \\
\text { investment and } \\
\text { its growth }\end{array}$ & $\begin{array}{c}\text { Equipment of sustainable industries, } \\
\text { a small share of state valuable } \\
\text { securities, a big share of valuable } \\
\text { securities of developed and medium- } \\
\text { sized, but reliable, emitters with a } \\
\text { long market history }\end{array}$ & $\begin{array}{c}\text { Medium risk level, } \\
\text { Diversified } \\
\text { profitability, liquidity }\end{array}$ & $\begin{array}{c}\text { Multidimensional, active, } \\
\text { calculative, }\end{array}$ \\
\hline Aggressive & $\begin{array}{c}\text { A speculative } \\
\text { game, the } \\
\text { possibility of } \\
\text { the rapid growth } \\
\text { of invested } \\
\text { funds }\end{array}$ & $\begin{array}{c}\text { Tangible assets of promising } \\
\text { industries, a high share of high- } \\
\text { yielding securities of small emitters, } \\
\text { venture companies, etc. }\end{array}$ & $\begin{array}{c}\text { High-risk level, } \\
\text { highly profitable, } \\
\text { highly liquid }\end{array}$ & $\begin{array}{c}\text { Multidimensional, active, } \\
\text { calculative, purposeful } \\
\text { rational }\end{array}$ \\
\hline Irrational & $\begin{array}{c}\text { No clear } \\
\text { objectives }\end{array}$ & $\begin{array}{c}\text { Randomly selected valuable } \\
\text { securities }\end{array}$ & $\begin{array}{c}\text { Low risk, non- } \\
\text { systemic }\end{array}$ & $\begin{array}{c}\text { Multidimensional, active, } \\
\text { purposeful rational }\end{array}$ \\
\hline
\end{tabular}

Source: compiled by the author according to the data (Gallagher 2017; Moran 1998)

Thus, the investment tools turn out to be an external element of the investors' behavior. They determine the models and character of the investment style. The investment capabilities of the tools mostly depend on the investment environment, in which they are used by the investor and the level of investment security or its parameters he sets.

Let us consider the interplay of such notions as the investment component of economic security and the investment policy. The investment component of economic security acts as a target object of the investment policy. The investment policy is a totality of measures of organizational and economic influence of the government bodies at all levels, focused on the provision of favorable conditions for attracting investments and increasing their efficiency. Thus, the investment component of economic security determines the initial conditions for the development of the investment policy, on the one hand, and turns out to be its result, on the other hand (Fig. 1).

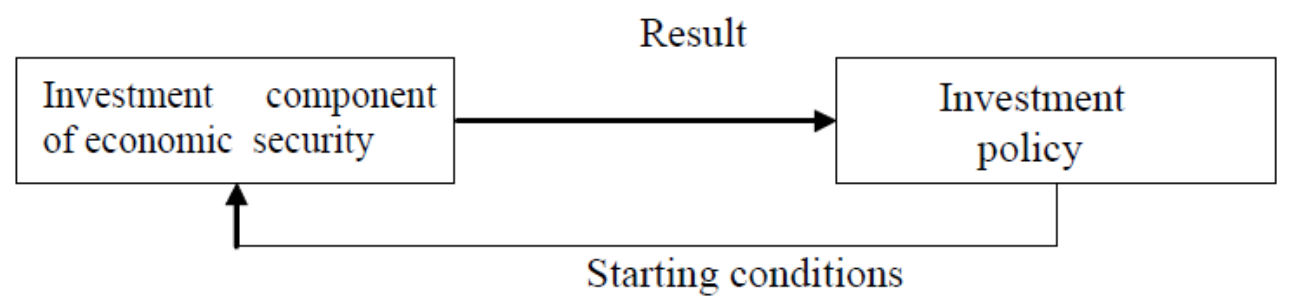

Figure 1. The interplay of the investment component of investment security and the investment policy Source: compiled by the author according to the data (Aitken and Harrison (1999) 
ENTREPRENEURSHIP AND SUSTAINABILITY ISSUES

ISSN 2345-0282 (online) http://jssidoi.org/jesi/

2021 Volume 8 Number 3 (March)

http://doi.org/10.9770/jesi.2021.8.3(24)

Make your research more visible, join the Twitter account of ENTREPRENEURSHIP AND SUSTAINABILITY ISSUES: @Entrepr69728810

The investment component of economic security provides more favorable conditions for investing under the influence of the investment policy. The efficiency of the investment policy is determined as a rate of indicator change of the investment component of economic security for the better. The improvement of the investment component of economic security, in its turn, positively affects the further improvement of the investment policy.

The share of accumulation of gross investments in GDP is the summarizing, or complex, an indicator of the investment security. The share of accumulation in GDP, for the developing countries, should constitute for 30$35 \%$ of the GDP volume. Thus, for example, in China, at the top of investment activity from 1990 to 2000, the share of accumulation in GDP exceeded 30\% and reached 33-34\% under the tempos of the GDP growth about 8$10 \%$ per annum (World Development Indicators: Structure of service imports 2020).

$$
\frac{\mathrm{GCF}}{G D P}=30-35 \%
$$

where: GCF - Gross capital formation, million US dollars, GDP - Gross domestic product, US dollars.

The increased attention to investment security is conditioned by the fact that investments are the foundation for the materialization of economic security, and, hence, the systematicity of tasks of the latter objectively requires activation of the investment processes to provide expanded reproduction, the formation of the potential for positive changes under the conditions of aggravation of socio-economic contradictions, threats to development, and independence of the country. Thus, based on the World Bank and International Finance Corporation experts estimates, under the increase in private investments in the developing countries by $1 \%$ to GDP, under other equal conditions, one observes the average annual growth ratio of the economy by $0.69 \%$. Moreover, the importance of providing investment security is determined by the need for keeping to the national interests in this sphere. Thus, among the national interests in the field of investment security, in particular, the following ones are highlighted (Alfaro and Chauvin 2016):

1) long-term: formation of the investment, and later - the innovative model of development, provision structural reorganization of the economy; formation of a favorable investment climate;

2) medium-term: provision of manageability of the process of the capital flow (with the consideration of the motives and trends of its international movement) to high-tech sectors of the economy, combining of investments with innovations, speeding up of industry modernization based on modern technologies, provision of qualitative composition of foreign investments, the development of share market, and the joint investment institutions;

3) short-term: avoiding of the banking system destruction, minimization of losses in the result of the global financial crisis, provision of the liquidity of enterprises and banks, avoiding exceptional dependence on foreign capital due to large volumes of external bond debt and attraction of additional international loans, protection of the economy from the expansion of the foreign TNCs under unacceptable conditions for the country, compliance with the norms of investment to GDP, and maintenance of the innovative directness of investments.

Nevertheless, from the above-mentioned national interests in the provision of investment security, in our view, it is legitimate to include only the formation of a favorable investment climate, avoiding of exclusive dependence on the foreign capital due to large volumes of foreign debt, and attraction of additional international loans, protection 
ENTREPRENEURSHIP AND SUSTAINABILITY ISSUES

ISSN 2345-0282 (online) http://jssidoi.org/jesi/

2021 Volume 8 Number 3 (March)

http://doi.org/10.9770/jesi.2021.8.3(24)

Make your research more visible, join the Twitter account of ENTREPRENEURSHIP AND SUSTAINABILITY ISSUES: @Entrepr69728810

of the economy from the expansion of foreign TNCs on unacceptable conditions for the country, compliance with the norms of investment in GDP, maintenance of innovative investments.

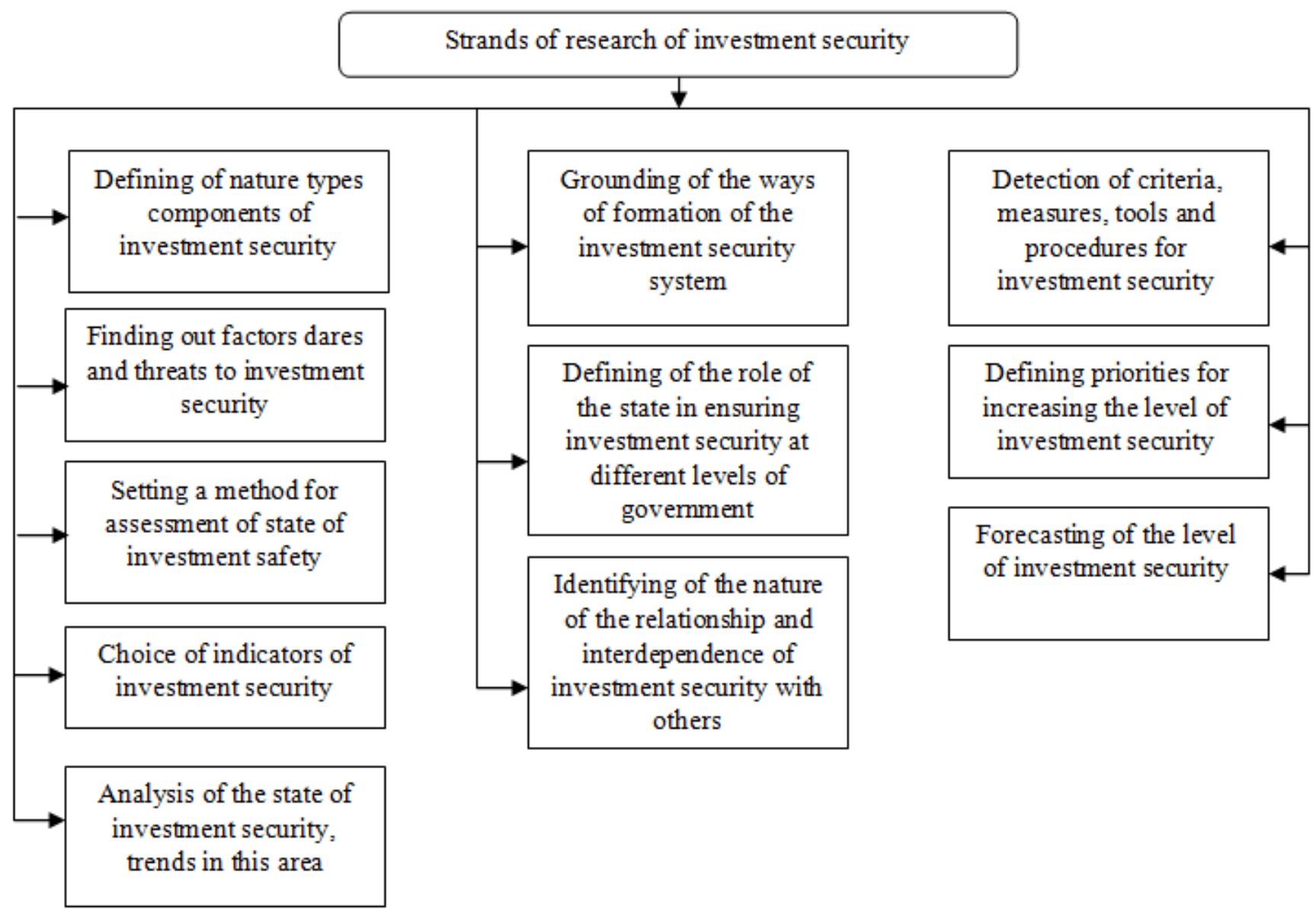

Figure 2. Directions of compliance and monitoring of the country's investment security

At the same time, we consider the national interests in the area of investment security as follows: the attraction of efficient (that will provide a greater gross economic effect than the rate of return, required by an investor, for covering the obligations on return of investments and borrowed funds) volume of investments; support of national commodity producers; increase in the employment of the country's population; and the attraction of modern technologies.

In the economic literature and scientific researches, the authors also speak about "investment security of the national economy," "regional investment security," "investment security of the socio-economic system," "security of the investment processes," "security of investment relations," "investment and economic security," "innovation and investment security," "innovation and investment security of innovative economic development," "economic security in the investment sphere," "economic security of the investment strategy implementation," "economic security of state investing of construction," "security of the foreign investments attraction," "innovation and investment component of the economic security," "financial and investment security," and "investment security of the social and economic system reproduction." 


\section{ENTREPRENEURSHIP AND SUSTAINABILITY ISSUES}

ISSN 2345-0282 (online) http://jssidoi.org/jesi/

2021 Volume 8 Number 3 (March)

http://doi.org/10.9770/jesi.2021.8.3(24)

Make your research more visible, join the Twitter account of ENTREPRENEURSHIP AND SUSTAINABILITY ISSUES: @Entrepr69728810

The development of theoretical and methodological fundamentals of investment security should be preceded by the definition of such principles with respect to investment in general. The held analysis has shown that the vast majority of scientific schools, theories, and concepts consider investment in the field of safety-related aspect, in particular: it identifies the connection between them and economic growth, accumulation, and external debt; determines factors, affecting the achievement of a proper level of investments, the outflow of the national capital abroad, as well as the risks, stimuli, and cyclicality of investing, demonstrates to the study of its uncertainty, and investor's behavior; puts an emphasis on the need for directing investments at innovations and diversification of the investment portfolio (Blomstrom et al 2000).

We think the study of the investment security should be carried out upon the directions, presented in Figure 2.

They should cover, first of all, the definition of content, types, components of investment security; clarification of factors, challenges, and threats to investment security; the development of assessment methodology of its state; the choice of the corresponding indicators; the analysis of the state of investment security and tendencies in this area. Of no less importance is the justification of approaches to the formation of the investment security system; the definition of the country's role in the provision of the latter at different management levels; the identification of the nature of interrelation and interdependence of investment security with other components of financial security and types of economic security.

And, finally, the obligatory directions of investment security research should be regarded as follows: identification of criteria, measures, tools, and procedures on its provision; the determination of its level advancement priorities; prediction of investment security level. One should mention that nowadays, there is no straightforward reasoned definition of investment security's nature. Thus, we think it would be inappropriate to state that the investment security is a complex indicator that has not been explored to the fullest extent, as, considering the multidimensionality of this category, there is no single measuring instrument for it.

The investment security has a rather simplifies definition as a state, under which are present: a) conditions of protection of investment resources, which are directed in the economy; b) the possibilities of the resources accumulation or capital investments; c) the capability of the national economic system to generate an investment process, supporting sustainable growth and strategic competitiveness of the country; d) access restrictions for foreign direct investments in the economic entities, whose activity is related to the realization of national interests; the condition of the country's provision with modern high-tech production tools (Morck, 2010).

At the same time, we think, if the positive aspect logically reflects the components of investment security, then it is at least incorrect to consider the combination of the state of the economy and its changes, guaranteed by the state as a normative aspect, as the competitiveness of the economy cannot be determined by the normative regulation alone (the thing the mentioned researcher puts an emphasis on).

We think that considering the multidimensional nature of the category "investment security of a country," the study of its content should be carried out with the use of a greater number of different conceptual approaches. We also think that the notion of the country's investment security should be considered as follows (Balasubramanyam et. al., 1996):

1) the achievement of the interests synchronization of subjects of the investment relationship for the provision of expanded reproduction in the country; restructuration and formation of the innovative model for the development of the national economy, the optimal distribution of investments upon regions and departments of the economic complex, reliability, and efficiency of investments; 


\section{ENTREPRENEURSHIP AND SUSTAINABILITY ISSUES}

ISSN 2345-0282 (online) http://jssidoi.org/jesi/

2021 Volume 8 Number 3 (March)

http://doi.org/10.9770/jesi.2021.8.3(24)

Make your research more visible, join the Twitter account of ENTREPRENEURSHIP AND SUSTAINABILITY ISSUES: @Entrepr69728810

2) avoiding of asymmetry (between the investment demand and supply, volumes of investments and the GDP growth, domestic and foreign investments, volumes and structure of investments in the regional and sectoral context) of the investment processes and losses for making unjustified unreasoned decisions;

3) the level of satisfaction of investment demand of the domestic economic entities, households, sectors of the economic complex, regions, and country in financial and material resources and intellectual property objects, required for adequate provision of their life activities and steady development;

4) investment attractiveness of investment objects, conditioned by the prospects of development, volumes, and prospects of product sales acceptable to investors, provision of services and execution of work, the efficiency of use of such assets, their liquidity, paying capacity, and financial firmness;

5) the availability of an investment doctrine, strategy, and policy, directed at the formation and efficient use of the investment capital of the investment process participants, the formation of the national economy's investment reserves, counteraction to unproductive capital outflow abroad, the introduction of the civilized regime of investments (withdrawal of investments), provision of a favorable investment climate, prevention of challenges and threats in the investment sphere, and reduction of risks of investment projects implementation.

The classification of the investment security varieties promotes a better understanding of its nature; presented in Table 2.

Table 2. Expanded classification of types of the country's investment security

\begin{tabular}{|c|c|}
\hline Criterion of classification & Types of investment security \\
\hline Management level & $\begin{array}{l}\text { households, economic entities, FIG, TNC, industry, region, sectors of the economy (types of } \\
\text { activity), investment market, interstate formations, and world community }\end{array}$ \\
\hline Geographic affiliation & national, international \\
\hline Object & $\begin{array}{l}\text { money resources; valuable securities; property; property right; other rights which have estimated } \\
\text { money value, invested in the objects of entrepreneurial and other activity for getting } \\
\text { profit/another effect/capitalization growth; budgetary investments; investments in human capital }\end{array}$ \\
\hline $\begin{array}{l}\text { Entities involved in investment } \\
\text { activities }\end{array}$ & $\begin{array}{l}\text { investors (individual and collective, institutional investors of the country), co-investors, } \\
\text { requestors, contractors, participants of public-private collaboration, guarantors, investment } \\
\text { recipients }\end{array}$ \\
\hline Investment form & $\begin{array}{l}\text { direct investment security (exchange), transitional investment (the use of private money capital), } \\
\text { direct investment (under the participation of the savings' owner and investment retailer), annuity } \\
\text { (investments which bring income to its owner at equal intervals) }\end{array}$ \\
\hline Investment directions & $\begin{array}{l}\text { security of investing in the diversification of the economy, import-substitution, innovations, } \\
\text { venture, social, and mixed investment }\end{array}$ \\
\hline Sources of investment resources & security of private, запозичених and engaged investment resources \\
\hline State & current, long-range \\
\hline Orientation & strategic, tactic; feasible, financial, and intellectual investing \\
\hline Investment scenario & $\begin{array}{l}\text { security of independent, security of alternative, the security of back-to-back, security of passive } \\
\text { investing }\end{array}$ \\
\hline Investment activity processes & $\begin{array}{l}\text { security of investment resources formation, the security of investment resources transformation, } \\
\text { the security of investment, the security of realization of investment }\end{array}$ \\
\hline
\end{tabular}


ENTREPRENEURSHIP AND SUSTAINABILITY ISSUES

ISSN 2345-0282 (online) http://jssidoi.org/jesi/

2021 Volume 8 Number 3 (March)

http://doi.org/10.9770/jesi.2021.8.3(24)

Make your research more visible, join the Twitter account of ENTREPRENEURSHIP AND SUSTAINABILITY ISSUES: @Entrepr69728810

\begin{tabular}{|l|l|}
\hline Investment risk level & $\begin{array}{l}\text { security of "forced" (legally determined) and social investments, investments in the creation of } \\
\text { the new ones and expansion of manufacturing departments and improvement of efficiency, } \\
\text { research/innovation }\end{array}$ \\
\hline Form of Investment Business & $\begin{array}{l}\text { security of corporate financing, project financing, investment lending, investment management, } \\
\text { investment banking (underwriting, servicing of merger/takeover of business agreements, } \\
\text { investment advice) }\end{array}$ \\
\hline Formalization & formalized, non-formalized \\
\hline Level & sufficient, insufficient; high, medium, low \\
\hline Dynamics & constant, increasing, running down, renewable \\
\hline
\end{tabular}

Source: Alfaro \& Chauvin (2016)

It must be said that investment security is inherent not only to the country, region, industry, and enterprise. We think, one should distinguish the investment security of households, business entities, FIGs, TNCs, industries of the economic complex, regions, sectors of the national economy (types of activity), an investment market, a socio-economic system, a country, the interstate formations (economic/monetary unions), and the global community (Figure 3). Herewith, one should mention that the country's investment security is the result of its components as the listed managerial levels of investment security cannot provide it without the country's participation.

Investment activity security is an unattainable component of investment security. In the context of investment security, it is legitimate to consider: 1) security of strategic (for the purpose of control over the investment object and making managerial decisions) and tactic (investment of funds in the real sector of the economy and purchasing of valuable securities for making a profit) investments; 2) security of investment resources formation, their transformation, investing (stability of income (interest money, dividends), invincibility at the investment capital market), and investment implementation; 3) security of investing in physical, monetary, and fictitious (property rights and intellectual valuables) assets (He 2011). That means one should speak of the security of the domestic and foreign investment, investing in the production of goods, provision of services, work performance; granting of a loan, a credit; purchasing of securities; 4) security of passive (which makes it possible to keep the achieved level) and active (which improves the competitiveness of the economic agent) investing; 5) security of "forced" (legally determined) and social investments as well as investing in the creation of the new ones and expansion of manufacturing departments and improvement of efficiency, research/innovation; 6) security of the particular investment projects (CCSI (formerly VCC) and WAIPA 2010). 
ENTREPRENEURSHIP AND SUSTAINABILITY ISSUES

ISSN 2345-0282 (online) http://jssidoi.org/jesi/

2021 Volume 8 Number 3 (March)

http://doi.org/10.9770/jesi.2021.8.3(24)

Make your research more visible, join the Twitter account of ENTREPRENEURSHIP AND SUSTAINABILITY ISSUES: @Entrepr69728810

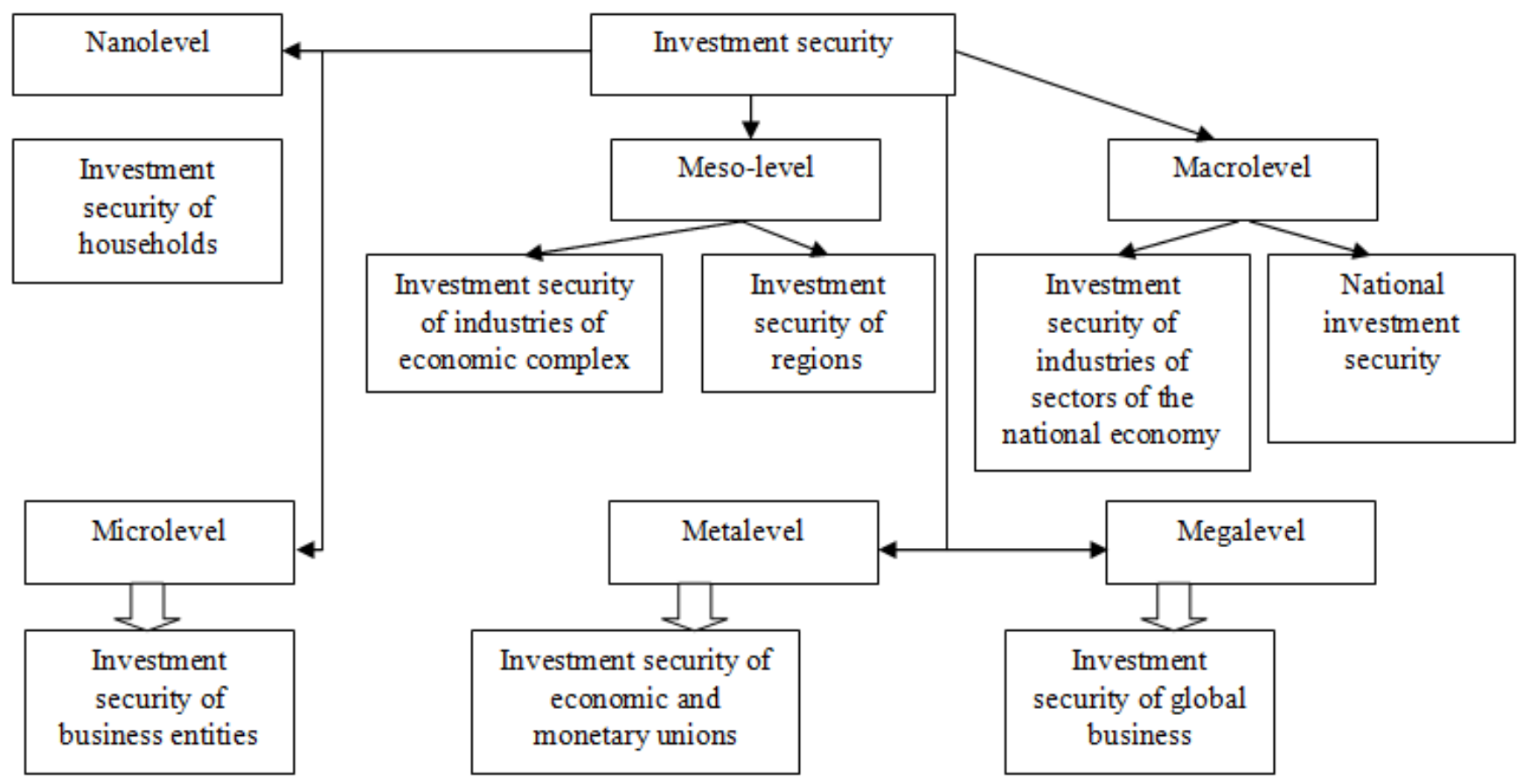

Figure 3. Investment security at different managerial levels of the national economy

At the same time, in this context, one should keep it in mind that no investment can simultaneously be characterized by such properties (peculiar to different investments) as attractiveness, invulnerability to shocks in the investment capital market, reliability, liquidity, and stability of income generation. It is necessary to consider the security of investing programs and sets of works. The security of policies of attracting domestic and foreign investments should be also put in the center of attention. Apart from that, it is reasonable to speak about the security of the investment projects, which can be achieved only under the condition of their full provision and threats' balancing acceptable to their participants.

Thus, (O'Connor, 2016) through the use of a general economic and theoretical approach to understanding any activity in the analysis of investment activity, namely, its interpretation as a unity of objectives, tools, results, and implementation mechanisms, reveals the relationship of categories, reflecting a subsystem of relationship, related to guaranteeing economic security, namely: "economic security" - "investment activity" - "investment process" "investment ensuring of economic security" - "investment security" - "an investment security mechanism" "investment policy." At the same time, under such an approach one observes the disruption of the existing causative-consecutive relationship between these mentioned categories. There is a clear correlation and interdependence between the country's investment security and its components (Figure 4).

To put it in other words, it is safe to say that the level of investment security significantly affects the levels of consumption and accumulation, demand and supply on the merchandise and financial markets, labor market, increase/decrease of business and investment activity of households, economic entities, industries, regions, sectors of the national economy, and, hence, determines the level of social and economic development of the country in general, stimulates/hinders economic growth (Golub et al 2011). At the same time, a comprehensive approach of 
ENTREPRENEURSHIP AND SUSTAINABILITY ISSUES

ISSN 2345-0282 (online) http://jssidoi.org/jesi/

2021 Volume 8 Number 3 (March)

http://doi.org/10.9770/jesi.2021.8.3(24)

Make your research more visible, join the Twitter account of ENTREPRENEURSHIP AND SUSTAINABILITY ISSUES: @Entrepr69728810

studying the theoretical and methodological foundations of the country's investment security requires a clear identification of the factors, determining its condition, and threats to it.

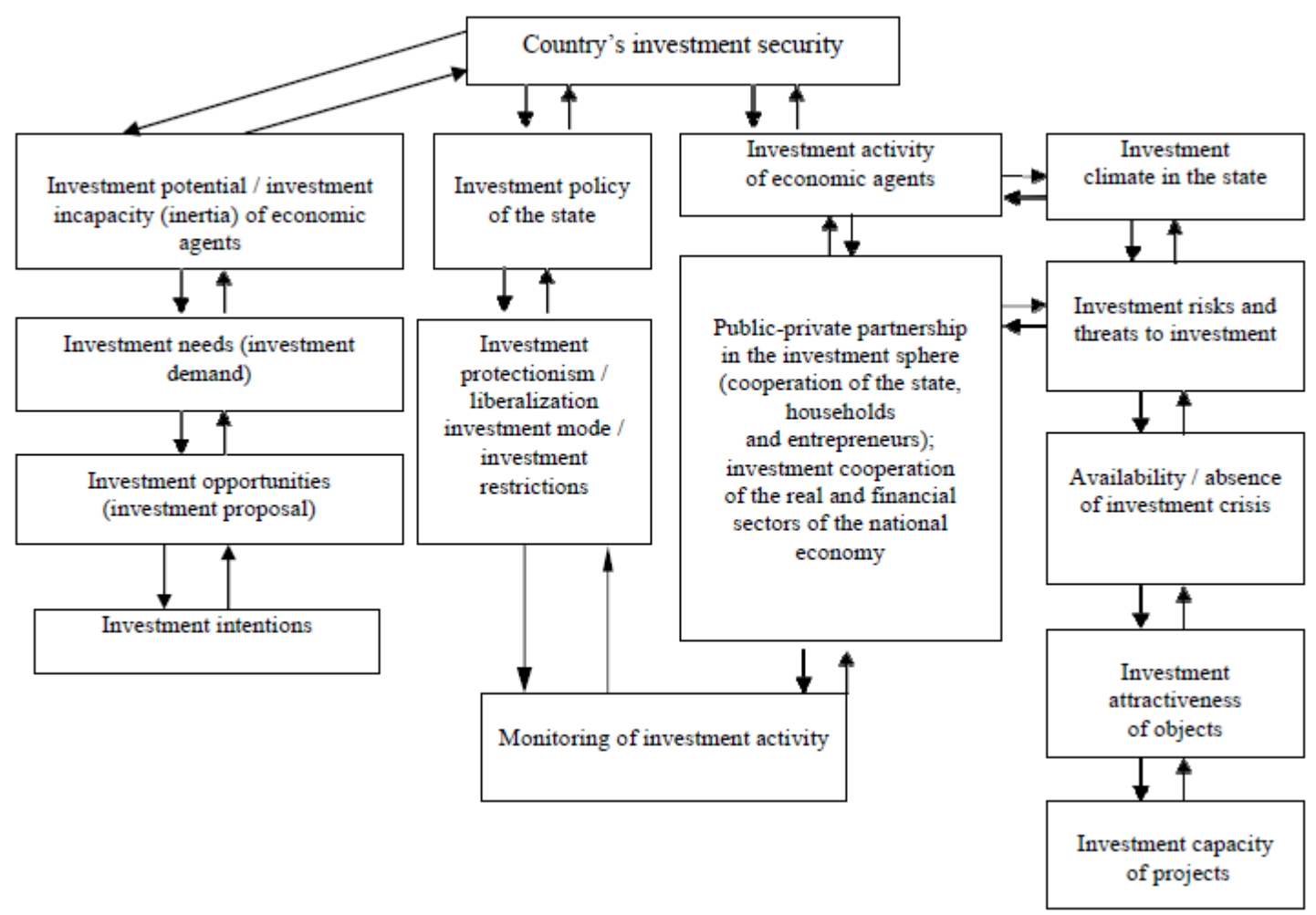

Figure 4. Interrelation and interdependence of the country's investment security components

State regulation of the investment component of economic security is considered as the totality of forms and ways, providing: the unification of state and private interests; generation of rational proportions between consumption, accumulation, and investment in the economy; combining of forecasting, indicative regulation, and measures of state influence on the investment market. The state performs its economic functions through the formation and spending of the state budget, which is a powerful lever of state regulation of the economy, and the manifestation of the investment policy. Thus, the overcoming of the economic crisis is possible via the identification of the real sources and volumes of government investments.

\section{Discussion}

Thus, the main threat to the country's investment security is the underfinancing of the economy's real sector. The problem of the investment security provision is especially important for developing countries, which should ensure the development of the market economy, overcome the deformations in the economy's structure, hold the renewal of products and productive apparatus in an industrial setting, and master new types of activity in the service industries. An additional point is that among the main threats for investment security also are: 


\section{ENTREPRENEURSHIP AND SUSTAINABILITY ISSUES}

ISSN 2345-0282 (online) http://jssidoi.org/jesi/

2021 Volume 8 Number 3 (March)

http://doi.org/10.9770/jesi.2021.8.3(24)

Make your research more visible, join the Twitter account of ENTREPRENEURSHIP AND SUSTAINABILITY ISSUES: @Entrepr69728810

- $\quad$ noncompliance with the norm of investing in relation to GDP;

- a low level of the investment climate upon all its components;

- the imperfection of the state monetary and credit policy, which hinders balancing between savings and investments;

- a shift in the investment structures (technological, reproductive, sectoral, regional, and by sources of investment)

- the absence of a strategy concerning direct foreign investments.

Following the orientation on the achievement of investment security as a subsystem of economic security, it is necessary to implement the following high priority tasks:

- the choice of a promising direction of investment;

- setting market and economic conditions for the investment of reproduction of the main funds and modernization and innovative accumulation of the stock capital;

- formation of a stable institutional structure, which provides stabilized conditions for performance of organizational-administrative functions;

- scientific substantiation of a reliable methodological system of complex assessment and analysis of efficiency of investment activity with the consideration of requirements of economic security;

- transformation of the economic structure for the transition to the production of science-intensive products with the consideration of an increase in the demand for goods and services in the markets;

- establishment of reliable financial prerequisites and conditions for provision of stable investing of innovative priorities, including through attraction of new sources of financing and investment process;

- the choice of reliable methods and legal ways of rights protection of private and foreign investors;

- formation of the investment activity insurance system, including shares and other valuable securities (via hedging of the investment risks and implementation of other methods);

- rationalization of tax payments, stipulated by current legislation, including tax optimization during the transition to an innovative economy.

The author's further research is focused on the analysis of the financial market indicators, signalizing the occurrence of threats for investment security.

\section{Conclusions}

The country's investment security should be considered as the achievement of the investment level, which makes it possible to please current investment needs of the national economy in terms of volume and structure of investments, with the consideration of efficient use and repayment of the invested funds, the optimal correlation between volumes of domestic and external investments, foreign investments in the country and domestic ones abroad, and support of the favorable national balance of payments.

At the same time, investment security has another component. Thus, the assessment of the market value of business or assets is needed nowadays not only within the framework of purchase and sale transactions, when granting loans and determining the object's collateral value, but also for making strategic and managerial decisions, and preparation of reports following the requirements of the international investment community. To ensure the financial security of the country, it is necessary to build the system of investment security with the consideration of the necessity of keeping to a well-balanced anti-inflationary policy, the achievement of the budget deficit reduction, and an increase in efficiency of a state borrowings policy. The provision of investment security should be built with the consideration of a dramatic reduction of the capital export abroad, a high level of 
ENTREPRENEURSHIP AND SUSTAINABILITY ISSUES

ISSN 2345-0282 (online) http://jssidoi.org/jesi/

2021 Volume 8 Number 3 (March)

http://doi.org/10.9770/jesi.2021.8.3(24)

Make your research more visible, join the Twitter account of ENTREPRENEURSHIP AND SUSTAINABILITY ISSUES: @Entrepr69728810

the interrelationship of international capitals, the absence of big volumes of foreign capital, intense competition between the spheres of its investment and countries, which engage foreign capital.

Investment security is determined by the structure and domination at the domestic market of specific investment motives, diversification level of investment sources; the volume of capital outflow; the level of return on invested funds; presence/absence of investment risk insurance; due diligence/dishonesty of investors' behavior; the level of coordination of managers' interests, majority, and minority owners; by the level of investors' awareness; the form of receiving investment income; the currency exchange rate regime and interest policy that were established in the country; the character of the depreciation policy; the time frames for making decisions on investment; and a clear investment policy, developed for the long term.

The level of investment security of the developing countries is still regarded as low. The investment climate, which forms in the country, may not stimulate the attraction of direct and portfolio investments. Successful investment attraction requires quality "goods," i.e. the investment-attractive business entities with a welldeveloped mechanism of investment consumption, with a modern management structure, without debts, etc. A lot of national companies today do not meet these requirements and, therefore, cannot become a real investment object. Thus, the country should implement the entire complex of practical measures on increasing the level of investment security within the lines of the national economy. The improvement of the investment climate, the increase of the investment activity, and, hence, the level of investment security are possible under the condition of establishing the corresponding financial and economic, normative and legal, and methodological bases, and concentration of resources for the implementation of a perfect investment policy.

\section{References}

Aitken, B.J. \& Harrison, A.E. (1999). Do Domestic Firms Benefit from Direct Foreign Investment? Evidence from Venezuela, American Economic Review, 89, 605-618.

Alfaro, L. \& Chauvin, J. (2016). Foreign Direct Investment, Finance, and Economic Development, URL: http://www.hbs.edu/faculty/Publication\%20Files/FDICapital_092116_FV_dc85d0a4-4964-4c2f-8d8b-2bc3b2b79e0d.pdf

Azam, M. et al. (2016). External Sources and Economic Growth - The Role of Foreign Remittances: Evidence from Europe and Central Asia. The Journal of Development, 50(2), 367-387.

Balasubramanyam, V.N., Salisu, M. \& Sapsford, D. (1996). Foreign Direct Investment and Growth in EP and IS Countries. Economic Journal, 106, 92-105.

Barro, R. J., \& Sala-I-Marting, X. (2003). Economic Growth. Cambridge MA: McGraw-Hill.

Benmamoun, M. \& Lehnert, K. (2013). Financing Growth: Comparing the Effects of FDI, ODA and International Remittances. Journal of Economic Development, 38(2), 43-65.

Blomstrom, M., Globerman, S. \& Kokko, A. (2000). The Determinants of Host Country Spillovers from Foreign Direct Investment CEPR discussion paper 2350 .

Borensztein, E., \& De Gregorio, J., \& Lee, J. W. (1998). How does foreign direct investment affect economic growth? Journal of International Economics, Vol. 45, 35-115. 


\section{ENTREPRENEURSHIP AND SUSTAINABILITY ISSUES}

ISSN 2345-0282 (online) http://jssidoi.org/jesi/

2021 Volume 8 Number 3 (March)

http://doi.org/10.9770/jesi.2021.8.3(24)

Make your research more visible, join the Twitter account of ENTREPRENEURSHIP AND SUSTAINABILITY ISSUES: @Entrepr69728810

Callanan, B. (2000). Ireland's Shannon Story, Irish Academic Press, Dublin.

CCSI (formerly VCC) and WAIPA (2010). Investment Promotion Agencies and Sustainable FDI: Moving Toward the Fourth Generation of Investment Policies.

Chehabeddine, M., \& Tvaronavičienè, M. (2020). Securing regional development. Insights into Regional Development, 2(1), 430-442. http://doi.org/10.9770/IRD.2020.2.1(3)

De Gregorio, Jose. (2003). The Role of Foreign Direct Investment and Natural Resources in Economic Development. Working Paper, No. 196. Central Bank of Chile, Santiago.

Eden, Lorraine (2012). Transfer price manipulation and developing countries. In Peter Reuter (editor). Draining Development? The Sources, Consequences and Control of Illicit Funds from Developing Countries. Washington, DC: The World Bank.

Gallagher, K.P. (2017). Global Energy Finance: A New Database (GEGI Policy Brief 002 - 03/2017).

Gestrin, Michael and Ana Novik (2015). Multinational enterprises and the Shifting Global Business Landscape. The E15 Initiative: Second Task Force Workshop on Investment Policy, June 9-10.

Golub, S.S., Kauffmann, C., \& Yeres, P. (2011). Defining and Measuring Green FDI, OECD Working Papers on International Investment, URL: http://www.oecd-ilibrary.org/content/workingpaper/5kg58j1cvcvk-en

He, Xiaoming (2011). State Multinationals: The impact of state ownership on international diversification and firm performance. Unpublished PhD dissertation. Texas A\&M University, Department of Management.

Hermes, N., \& Lensik, R. (2003). Foreign direct investment, financial development and economic growth. Journal of Development Studies, Vol. 38, 142-163.

Lall, S. (2000). FDI and development: research issues in the emerging context. Policy Discussion Paper 20, Centre for International Economic Studies, University of Adelaide.

Mazzanti, M., Mazzarano, M., Pronti, A., Quatrosi, M. (2020). Fiscal policies, public investments and wellbeing: mapping the evolution of the EU. Insights into Regional Development, 2(4), 725-749. http://doi.org/10.9770/IRD.2020.2.4(1)

Moran, T.H. (1998). Foreign Direct Investment and Development. Institute for International Economics, Washington, DC.

Morck, Randall (2010). The riddle of the great pyramid. In Eds. Colpan AM, T. Hikino, and J.R. Lincoln. The Oxford Handbook of Business Groups. Oxford University Press: New York, NY, 602-628.

O’Connor, S. (2016). Measuring the Value of “Green” Foreign Direct Investment in the United Kingdom (UK Office for National Statistics),

URL:

https://www.ons.gov.uk/economy/nationalaccounts/balanceofpayments/adhocs/005648greenforeigndirectinvestmentexperimentalestimates

Vasconcelos, V.V. (2021). Social justice and sustainable regional development: reflections on discourse and practice in public policies and public budget. Insights into Regional Development, 3(1), 10-28. https://doi.org/10.9770/IRD.2021.3.1(1)

Williams, K. (2016). Remittances and Financial Development: Evidence from Sub-Saharan Africa, African Development Review, 28.3, 357-367.

World Development Indicators: Structure of service imports (2020). URL: http://wdi.worldbank.org/table/4.7 


\section{ENTREPRENEURSHIP AND SUSTAINABILITY ISSUES}

ISSN 2345-0282 (online) http://jssidoi.org/jesi/

2021 Volume 8 Number 3 (March)

http://doi.org/10.9770/jesi.2021.8.3(24)

Make your research more visible, join the Twitter account of ENTREPRENEURSHIP AND SUSTAINABILITY ISSUES: @Entrepr69728810

Xiao, Qin Fan \& Paul, M. Dickie (2000). The Contribution of Foreign Direct Investment to Growth and Stability. ASEAN Economic Bulletin, 17(3), 312-23.

Xu, B. (2000). Multinational enterprises, technology diffusion, and host country productivity. Journal of Development Economics, 62, 477493.

Lidiia KARPENKO, Doctor in Economics, Professor, Odessa Regional Institute for Public Administration of the National Academy for Public Administration under the President of Ukraine

ORCID ID: orcid.org/0000-0002-2888-2477

Oleksandr IGNATENKO, Doctor of Science in Public Administration, Professor, National Academy of Public Administration under the President of Ukraine,

ORCID ID: orcid.org/0000-0001-9088-5794

Olena TARANENKO, PhD (Public Administration), National Academy of Public Administration under the President of Ukraine ORCID ID: orcid.org/0000-0002-1596-9493

Iryna OLIINYK, Post-graduate student of the National Academy of Public Administration under the President of Ukraine ORCID ID: orcid.org/0000-0002-4263-1324

Ripsime KHRENOVA-SHYMKINA, Post-graduate student of the National Academy of Public Administration under the President of Ukraine

ORCID ID: orcid.org/0000-0003-2566-9782

Copyright (C) 2021 by author(s) and VsI Entrepreneurship and Sustainability Center

This work is licensed under the Creative Commons Attribution International License (CC BY).

http://creativecommons.org/licenses/by/4.0/

cC (i) Open Access 